Revista de la red interuniversitaria de estudios sobre las literaturas rioplatenses contemporáneas en Francia

6 | 2011

Juan José Saer. archivos, memoria, critica

\title{
Anexo II. La mesa del escritor
}

\section{Julio Premat}

\section{OpenEdition}

Journals

\section{Edición electrónica}

URL: http://journals.openedition.org/lirico/797

DOI: $10.4000 /$ lirico.797

ISSN: 2262-8339

Editor

Réseau interuniversitaire d'étude des littératures contemporaines du Río de la Plata

\section{Edición impresa}

Fecha de publicación: 1 diciembre 2011

Paginación: 211-212

ISBN: 2-9525448-5-9

ISSN: 2263-2158

\section{Referencia electrónica}

Julio Premat, « Anexo II. La mesa del escritor », Cuadernos LIRICO [En línea], 6 | 2011, Publicado el 08 octubre 2012, consultado el 15 septiembre 2020. URL : http://journals.openedition.org/lirico/797

\section{(c) $(7)(2)$}

Cuadernos LIRICO está distribuido bajo una Licencia Creative Commons Atribución-NoComercialSinDerivar 4.0 Internacional. 


\section{ANEXO II LA MESA DEL ESCRITOR}

La lista que sigue retoma los documentos que se encontraban sobre la mesa de Saer cuando falleció y que fueron utilizados para la escritura de La grande. Por supuesto, también estaban allí los trece cuadernos de notas y manuscritos sobre esa novela, una computadora portátil y una serie de post-it y papeles con notas breves. El conjunto del material se encuentra en los Juan José Saer Manuscripts de Princeton.

\section{Libros y revistas}

La sibila. Ponga la suerte de su lado. Conozca las antiguas claves de los sueños y sus números equivalentes, Buenos Aires, Need, 1997.

César Rappalini, Aves del Uruguay, Uruguay, Arca, 1968.

Litoral/Nueva arquitectura. Exposición/manifiesto. Concurso de casas recientes, con fotos.

Revue d'Esthétique, nouvelle série, $\mathrm{n}^{\circ}$ 8, 1985. Número especial dedicado a Adorno.

Mario Daniel Andino, El último malón de los indios mocovíes, Santa Fe, UNL, 1998.

Memorias de papel sensible. Reseña fotográfica de la Ciudad de Santa Fe, antología fotográfica publicada por el diario El Litoral, 1998.

Le guide Hachette des vins, prospecto publicitario de la edición del 2004.

Gustavo Choren, El gran libro del malbec argentino, Buenos Aires, Planeta, 2003.

Eduardo Haene, Gustavo Aparicio, 100 árboles, Buenos Aires, Albatros, 2001.

Raúl Serroni-Copello, Encuentros con Mario Bunge, Buenos Aires, ADIP, 1989.

Vistas de la provincia de Santa Fe 1888-1892. Fotografías de Ernesto H. Schlie, idea, selección y prólogo de Luis Príamo, Santa Fe, Diario El Litoral, 2000.

Martín Fierro y J. Hernández al comienzo del siglo XXI, catálogo de exposición en la Biblioteca Nacional, 2000

Juan Carlos Funes, Historias de la vigilia y del sueño, Santa Fe, Edición de autor, 2000. 
Salah Stétié, Le vin mystique et autres lieux spirituels de l'Islam, París, Albin Michel (col. Spiritualités vivantes), 2002.

Miguel Cello, Calles de Santa Fe. ¿Por qué? ¿Por quién?, Santa Fe, UNL, 1997.

Jorge Taverna Irigoyen, Cien años de pintura en Santa Fe, Santa Fe, UNL / Municipalidad de la ciudad de Santa Fe, 1992.

Eugenio Castelli, Un siglo de literatura santafesina. Poetas y narradores de la provincia (1900-1995), Santa Fe, Ediciones culturales santafesinas, Gobierno de Santa Fe, 1998.

Serodino. Un noble pueblo santafesino. Libro del Centenario (1886-1986), Serodino, Edición de la comuna de Serodino, 1986.

Jorge Dengis, Manual del vino argentino, Buenos Aires, Albatros, 1994.

Hoy y mañana. La revista que se compra pero que no se vende, cinco números de 2001-2002. Mensuario santafesino de análisis de política y cultura dirigido por Rogelio Alaniz.

Club del vino, algunos ejemplares de la revista mensual ( $n^{\circ} 67,68,69,70$, 75, 96), de 1994-1995.

40 años de la tertulia literaria hispanoamericana, prospecto del ICI (Instituto de cooperación iberoamericana).

Orígenes e identidad de los santafesinos. Santa Fe, suplementos de El Litoral,: «Instituciones árabes», «La llegada de los árabes».

Hojas sueltas de enciclopedia no identificable, letras o y p sobre pájaros.

Prospectos de El club del vino (Buenos Aires) y La grande épicérie de Paris sobre botellas grandes especiales.

\section{Fotos y postales}

20 postales de la ciudad de Santa Fe y alrededores.

2 de Rosario

1 río Gualeguay

2 varias (asado, río).

29 fotos. Varias de inundaciones y de la calle San Martín. Algunas personales (en casa de Raúl Beceyro y Marylin Contardi) o en presentación con Jean Andreu.

1 con alfabeto de signos de sordos. 